\title{
First record of the noncalcareous macroalga Perissothallus from shallow-water deposits (Pennsylvanian) in the Kladno-Rakovník Basin, Czech Republic
}

\author{
JOSEF PŠENIČKA \& MICHAEL KRINGS
}

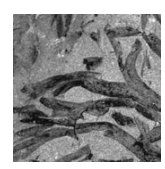

\begin{abstract}
The fossil genus Perissothallus is used for adpression fossils of late Palaeozoic noncalcareous freshwater algae consisting of erect, cylindrical branches that radiate from a central holdfast and dichotomize repeatedly. The taxon currently includes $P$. versiformis from the Upper Pennsylvanian of North America and $P$. densus from the Lower Permian of Germany. In this paper we describe a third species, Perissothallus dekovensis nov. sp., from the Gzhelian (Stephanian B; Upper Pennsylvanian) of the Kladno-Rakovník Basin, Czech Republic. The new species differs from the previously described forms with regard to thallus size and branching pattern of the erect parts. Sedimentological data and the fossils that co-occur with the algal thalli suggest that $P$. dekovensis lived in shallow-water areas of a lake or abandoned channel that was surrounded by tree ferns, cordaites (especially Poacordaites-type), and lycopsids. $\bullet$ Key words: Carboniferous, Kounov Member, palaeoecology, Perissothallus densus, Schizopteris, thallus.
\end{abstract}

PŠENIČKA, J. \& KRINGS, M. 2016. First record of the noncalcareous macroalga Perissothallus from shallow-water deposits (Pennsylvanian) in the Kladno-Rakovník Basin, Czech Republic. Bulletin of Geosciences 91(1), 57-64 (5 figures). Czech Geological Survey, Prague. ISSN 1214-1119. Manuscript received July 28, 2015; accepted in revised form November 8, 2015; published online December 15, 2015; issued March 17, 2016.

Josef Pšenička (corresponding author), Centrum of Palaeobiodiversity, West Bohemian Museum in Pilsen, Kopeckého sady 2, 30100 Pilsen, Czech Republic; jpsenicka@zcm.cz・Michael Krings, Department für Geo- und Umweltwissenschaften, Paläontologie und Geobiologie, Ludwig-Maximilians-Universität, and Bayerische Staatssammlung für Paläontologie und Geologie, Richard-Wagner-Straße 10, 80333 Munich, Germany; m.krings@lrz.uni-muenchen.de

\begin{abstract}
Algae today occur in a wide variety of environments, ranging from open oceans to desert sand (e.g. Andersen 1992, Norton et al. 1996); many forms thrive as epiphytes and endophytes on and in other organisms (Goff 1983, Chapman $\&$ Waters 1992). However, large algae with complex multicellular thalli ("macroalgae") are typically restricted to aquatic habitats (Graham et al. 2009, Keith et al. 2014).

The fossil record of algae is extensive and ranges from the Mesoproterozoic ( 1.2 Ga) (Butterfield 2000) to Quaternary (Garcia \& Playford 2007, Taylor et al. 2009). Certain groups of unicellular algae, charophyte oogonia (gyrogonites), and the remains of calcareous macroalgae from marine and brackish water environments are abundant and diverse as fossils because their thick walls and/or calcium-based skeletons are readily preserved (e.g., Flügel 1977, Tappan 1980, Riding 1991). Conversely, noncalcareous macroalgae are rare as fossils. The fossil representatives reported to date for this group likely represent only an infinitesimal portion of the species diversity that
\end{abstract}

existed in various aquatic environments throughout geological time (Krings \& Mayr 2004, Krings \& Butzmann 2005). Nevertheless, noncalcareous macroalgae play important roles in the functioning of many aquatic ecosystems today (e.g., Round 1981), and likely were similarly important in the past. As a result, a detailed documentation of their past diversity and distribution is important in fully understanding the functioning and evolution of ancient aquatic ecosystems. Unfortunately, noncalcareous macroalgae become preserved only where the depositional environment provides ideal conditions for fossilization. Moreover, impression/compression fossils of these organisms may easily be confused with other plant remains such as bryophytes, aphleboid foliage of several vascular plants, and roots, and thus are probably often overlooked or misinterpreted (Krings et al. 2007).

One excellent example is Schizopteris Brongniart, initially described for Carboniferous impression/compression fossils of aphleboid foliage of uncertain affinity 


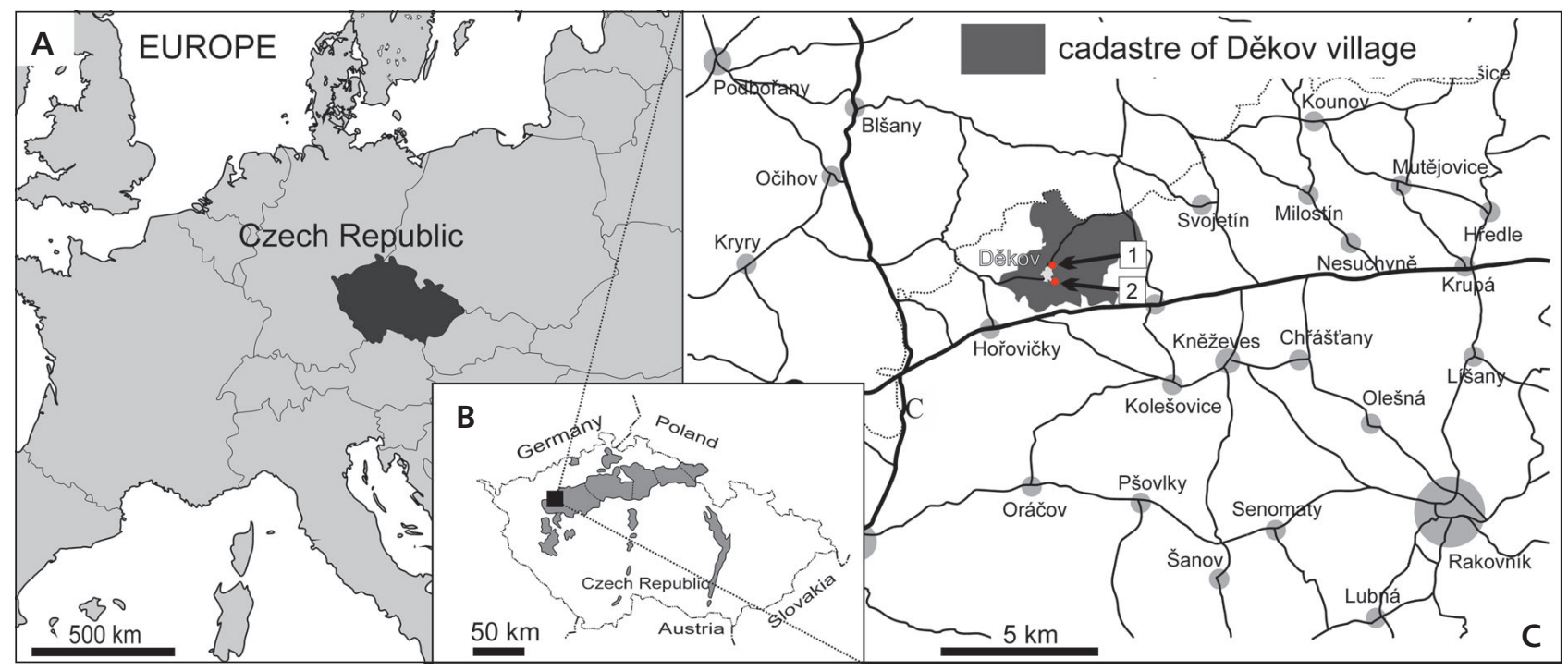

Figure 1. Geographic position of the Děkov locality. $\bullet$ A - location of Czech Republic in Europe. $\bullet$ B - late Palaeozoic continental basins in Czech Republic. $\bullet \mathrm{C}$ - detail of the Rakovník area, showing Děkov village and the two localities mentioned in the text: 1 - abandoned quarry northeast of Děkov village, 2 - abandoned quarry southeast of Děkov village.

(Brongniart 1828-1837). Barthel (1982), Kerp \& Fichter (1985), and Krings et al. (2007) suggested that some of the fossils conventionally assigned to Schizopteris do not represent aphleboid foliage, but rather thalli of noncalcareous algae similar in overall morphology to certain extant members of the Chlorophyta (green algae), Phaeophyceae (brown algae), and Rhodophyta (red algae). Krings et al. (2007) therefore formally excluded the algae from Schizopteris and introduced a new genus, Perissothallus Krings et al., for these fossils, with two species, $P$. versiformis Krings et al. from the Upper Pennsylvanian of North America and $P$. densus Krings et al. from the Lower Permian of Germany. However, these authors acknowledged that many more specimens and forms need to be critically analyzed and formally described to complete the separation of the algae from Schizopteris, and to document the geographic distribution and stratigraphic range of these aquatic plants. For example, several impression/compression fossils of aphleboid foliage from the Carboniferous of the Czech Republic have been described under the name Schizopteris (e.g., Sternberg 1838, Němejc 1938). The paper presented here is the first record of Perissothallus from the Czech Republic based on specimens from the Slaný Formation (Gzhelian/Stephanian B) at Děkov, northwest of Rakovník. The thalli resemble Perissothallus densus, but are considerably smaller and display a different branching pattern of the erect parts. As a result, we have instituted a third species of Perissothallus, for which the name $P$. dekovensis nov. sp. is proposed. This discovery contributes to our understanding of the diversity, geographical distribution, and geological range of the late Palaeozoic algal genus Perissothallus.

\section{Geological setting, material and methods}

The specimens come from an abandoned quarry located near the village of Děkov, $\sim 15 \mathrm{~km}$ northwest of Rakovník (Kladno-Rakovník Basin), Czech Republic (Fig. 1C loc. 1). They were collected by J. Šetlík in the 1960s and are currently in the Czech Geological Survey, Prague, under numbers ZŠ 539 through 544. The fossil thalli are preserved as impressions/black compressions on an ochergray mudstone/siltstone matrix; co-occurring with the thalli on the same slabs are fragmented remains of plant roots and abundant detritus.

The strata exposed at the Děkov locality have been assigned to the Kounov Member of the Slaný Formation (Pennsylvanian) based on the presence of thin, low grade coal layers intercalated with a whitish clay/sand layer (up to $7 \mathrm{~mm}$ thick) which has been interpreted as a so-called "Kamínek", a volcanogenic sediment typical of the lower Kounov Coal (Němejc \& Šetlík 1950). The Kounov Member is part of the Slaný Formation that extends from Pilsen to the Kladno-Rakovník and Mšeno-Roudnice basins (Pešek 2004). The formation represents a complex of fluvio-lacustrine deposits (30-50 m thick) composed of whitish-grey arkosic sandstone or arkoses that are locally rich in grey claystone and mudstone, and contains several coal seams of the Kounov Group (Pešek 1994). The Kounov Group is subdivided into a Lower and Upper Kounov Coal, the former characterized by the presence of a distinctive argillized volcanogenic "Kamínek" bed (Obrhel 1960; Pešek 1994, 2004). Kamínek is one of the most important correlation markers in basins of central and western Bohemia (Pešek 1994, 2004). 
The geological setting at Děkov reflects the marginal development of the Lower Kounov Coal. The coal occurs in thin layers representing short episodes of watertable fluctuation. Precursor of the Kounov Coal probably was a planar peat swamp that experienced occasional flooding. The geological profile for the area was compiled by Němejc \& Šetlík (1950) based on data obtained from the basal part of the upper dirty coal exposed in an abandoned quarry southeast of Děkov (Fig. 1C - loc. 2). The source locality of the fossils described here (Fig. 1C - loc. 1) is included in the same stratigraphic context. The sequence (Fig. 2) begins with massive arkoses deposited in a high-energy environment, possibly of fluvial origin. The arkoses are conformably overlain by grayish-green mudstones ( $c$ a 150 m thick) deposited in a low-energy environment, possibly lacustrine or an abandoned channel fill. This part of the profile consists of sediments indicative of a shallow-water environment. The overlying dirty coal ( $70 \mathrm{~mm}$ thick) indicates formation via paludification. The horizon between the arkoses and dirty coal contains abundant roots and fragmentary remains of aerial plant parts. The algal thalli come from a thin layer of mudstone situated immediately below the lower dirty coal (see Fig. 2). Mudstone $(\sim 500 \mathrm{~mm})$ lacking fossils occurs above this coal, at least according to Němejc \& Šetlík (1950), however, these authors reported roots from the same stratigraphic interval exposed in the quarry southeast of Děkov (Fig. 1C loc. 2). Both quarries are today closed and recultivated, which unfortunately precludes verification of Němejc \& Šetlík's (1950) description of the geological sequence and a more precise sedimentological interpretation of the alga-bearing section.

\section{Systematic palaeobotany}

Algae incertae sedis

\section{Fossil genus Perissothallus Krings et al., 2007}

\section{Fossil species Perissothallus dekovensis sp. nov.}

Holotype. - Specimen illustrated in Fig. 3A and B, housed in the collection of the Czech Geological Survey, Prague, Czech Republic (number ZŠ 593).

Etymology. - The epithet "dekovensis" refers to the provenance of the material.

Type locality. - Abandoned quarry southeast of the village of Děkov (50¹0’24.7” N; 133’ 19.8” E).

Type horizon. - Kounov Coals (layer directly below Lower

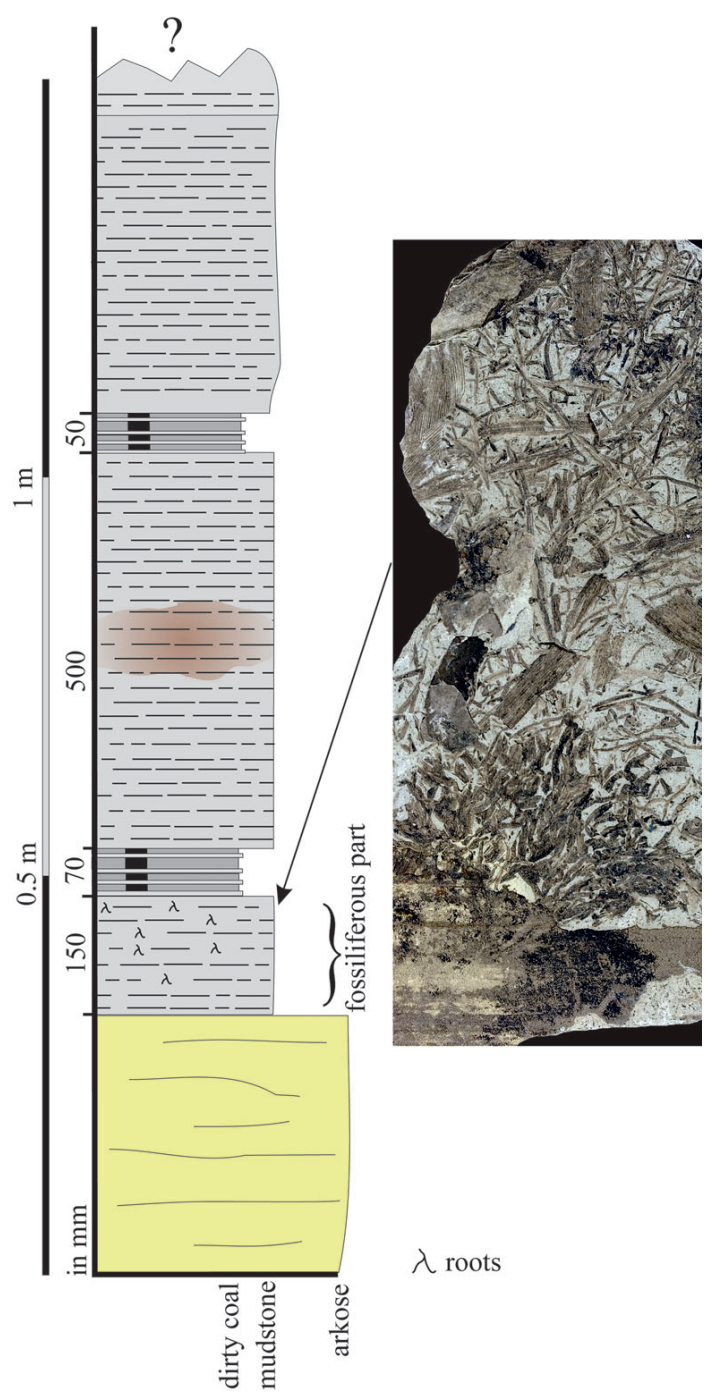

Figure 2. Sediment succession in quarry northeast of Děkov village according to Němejc \& Šetlík (1950), showing dirty coals, mudstone deposits, and arkoses; photograph shows slab containing algal thalli, roots, and plant detritus.

Kounov Coal), Kounov Member, Slaný Formation, lowermost Gzhelian (Stephanian B), Upper Pennsylvanian.

Diagnosis. - Thallus small, sessile, solitary, relatively loosely organized; holdfast prominent, hemispherical; erect branches numerous, extending from entire surface of holdfast; branches cylindrical, usually up to $35 \mathrm{~mm}$ long and dichotomizing 5-6 times; branch segments (between two dichotomies) mostly between 3 and $10 \mathrm{~mm}$ long; ultimate segments short, often somewhat club-shaped, tips rounded or somewhat tapering.

Description. - The thallus of Perissothallus dekovensis (Fig. 3A-C) is relatively loosely organized and consists of numerous $(>25)$ erect branches that extend from a prominent, more or less hemispherical or somewhat cylindrical 
holdfast structure, which is $7.5 \mathrm{~mm}$ wide and $3.5 \mathrm{~mm}$ high in the specimen shown in Fig. 3A and B (arrow). The holdfast in this specimen is attached to what appears to be a segment of a large cordaitalean branch. We are unable to determine whether the two elongate structures that appear to extend from the holdfast into the cordaitalean branch belong to the algal thallus or represent preservation artifacts. The erect thallus branches measure 20-25(-35) mm long and $1-1.5 \mathrm{~mm}$ wide, and were probably more or less cylindrical in vivo. They dichotomize irregularly, usually 5-6 times (Figs 3E, 4). Branch segments between two dichotomies range from $<3$ to $>10 \mathrm{~mm}$ long. Proximal branch segments often appear distinctly narrower than the distal ones (Figs 3E, 4). Ultimate branch segments are short and usually taper towards the tip or possess a rounded apex (Fig. 3D). Distal dichotomies sometimes show a faint constriction immediately below the dichotomy (arrow in Fig. 3E).

One specimen from the Šetlík collection is distinctly more compact in appearance than the others (Fig. 3F). Unfortunately, the number of dichotomies in this thallus cannot be determined because the branches are too densely compacted. This specimen is $>60 \mathrm{~mm}$ in diameter, and thus exceeds the size of all other specimens of Perissothallus dekovensis.

Remark. - Features of the specimen illustrated in Fig. 3F are not included in the diagnosis because it is impossible to determine whether this specimen represents a large and unusually compact individual of Perissothallus dekovensis or belongs to a different species (see Discussion section below).

\section{Discussion}

\section{Comparisons}

The genus Perissothallus initially comprised two species, i.e. Perissothallus versiformis from the Upper Pennsylvanian of North America and $P$. densus from the Lower Permian of Germany (Krings et al. 2007). Krings et al. (2007) used three basic features to distinguish algae from Schizopteris-type aphleboid foliage. These include (i) the overall appearance and morphology of the fossils with no consistent internal or surface structures (e.g., venation) visible, (ii) the presence of a basal holdfast, and (iii) variable morphologies suggestive of different developmental stages. Perissothallus dekovensis described in this paper is consistent with the first two of these features. However, the spe- cies is represented by only two complete thalli (Fig. 3A, C) that are generally similar in morphology. Both thalli appear to be mature, based on the degree of differentiation of the erect branches, which is comparable to that seen in the mature specimens of $P$. versiformis and $P$. densus (Krings et al. 2007, figs 1, 8-10, 12, 13). Variable morphologies suggestive of developmental stages are not present in the material from the Czech Republic, with the possible exception of the specimen illustrated in Fig. 3F, which might be an old or exceptionally large of $P$. dekovensis, but also might represent a different species.

If our interpretation of the specimens illustrated in Fig. $3 \mathrm{~A}$ and $\mathrm{C}$ as mature thalli is correct, then Perissothallus dekovensis differs from both previously described taxa primarily with regard to size. Perissothallus versiformis and $P$. densus are considerably larger than $P$. dekovensis (e.g., branches are up to $70 \mathrm{~mm}$ long in $P$. densus vs $35 \mathrm{~mm}$ in $P$. dekovensis). Moreover, $P$. dekovensis differs from $P$. versiformis in the branching pattern of the erect parts, which uniformly dichotomize in the former but demonstrate a more irregularly monopodial branching pattern in the latter species. In addition, the spacing of the erect branches in $P$. densus is more dense than in $P$. dekovensis. Finally, thalli extending from elongate prostrate axes, a typical feature of $P$. densus (see Krings et al. 2007, figs $6,10,11$ ), have not been observed in $P$. dekovensis. However, the latter difference might also represent a small sample size for $P$. dekovensis. The possibility also exists that some or all of the features used to delimit $P$. dekovensis from $P$. versiformis and $P$. densus are not diagnostic, but rather represent patterns of intraspecific variability. However, since our analysis is restricted to the morphology of sterile thalli, we are confident in interpreting the specimens illustrated in Fig. 3A-C as a separate fossil species.

\section{Palaeoenvironment}

The fossils described in this paper come from sediments deposited in an intramontane basin that, together with several other basins, developed in central and western Bohemia (henceforth abbreviated CWB) during the Pennsylvanian as a result of the Variscan Orogeny (Krs \& Pruner 1995; Pešek 1994, 2004; Opluštil \& Pešek 1998). The basin fills consist of up to $1400 \mathrm{~m}$ of Moscovian/Gzhelian sediments, which have been subdivided and formally described as Kladno (humid phase), Týnec (arid phase), Slaný

Figure 3. Perissothallus dekovensis nov. sp. $\bullet$ A - holotype. Mature thallus attached to cordaite branch co-occurring with abundant roots and plant detritus; specimen ZŠ 539; scale bar $=20 \mathrm{~mm}$. $\bullet \mathrm{B}$ - detail of Fig. 3A, showing system of erect branches emerging from holdfast (arrow); scale bar = 10 mm. - $\mathrm{C}$ - second specimen of complete mature thallus; specimen ZŠ 540; scale bar $=10 \mathrm{~mm}$. $\bullet$ D - slightly widened distal (ultimate) units of erect branches; specimen ZS 540; SEM; scale bar $=2 \mathrm{~mm}$. $\bullet \mathrm{E}$ - branch of mature thallus; note that proximal branch segments (arrow) appear narrower than the distal ones; specimen ZŠ 541; scale bar $=10 \mathrm{~mm}$. $\bullet \mathrm{F}$ - large compact thallus; specimen ZŠ 543; scale bar $=10 \mathrm{~mm}$. 

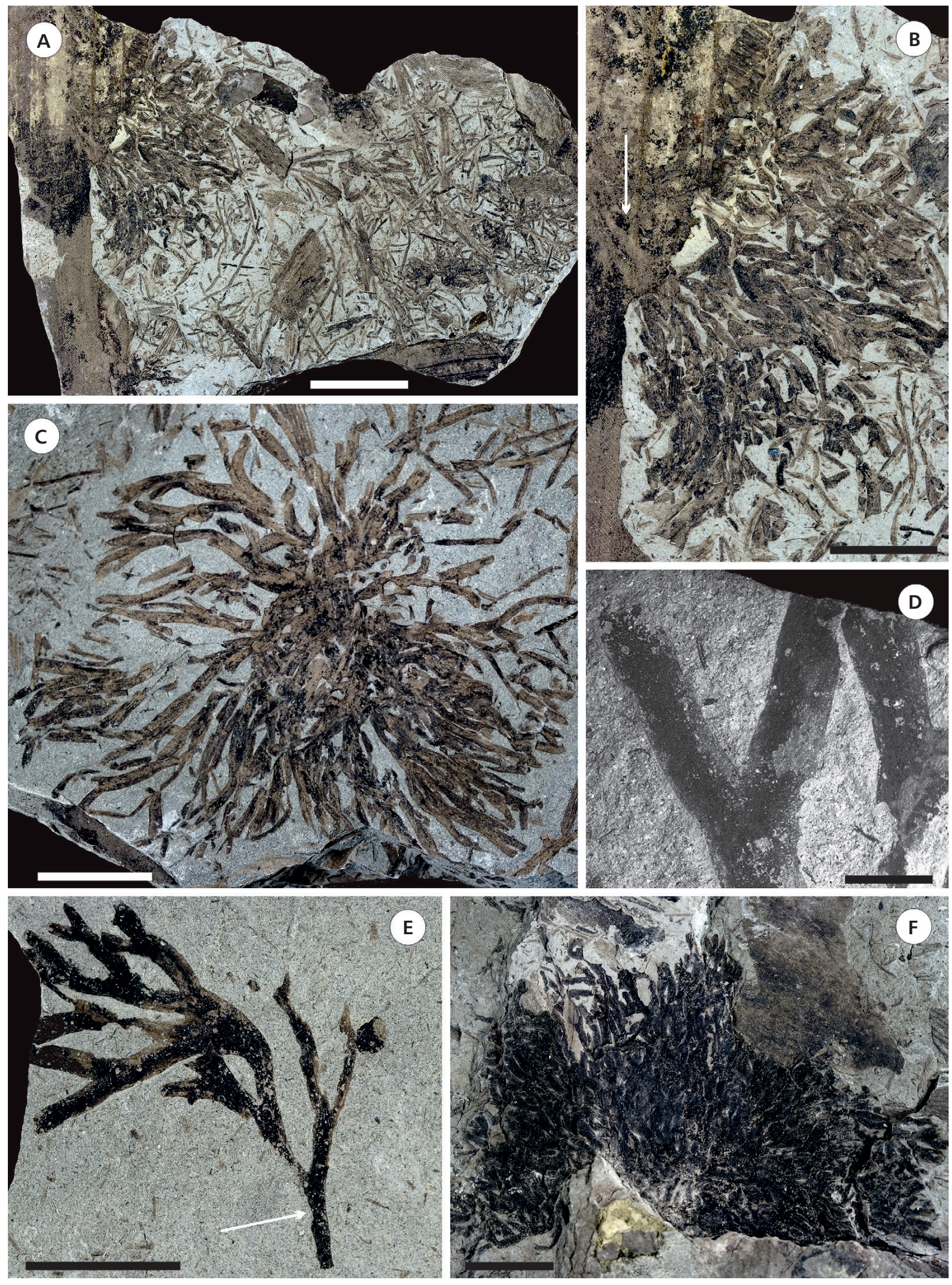


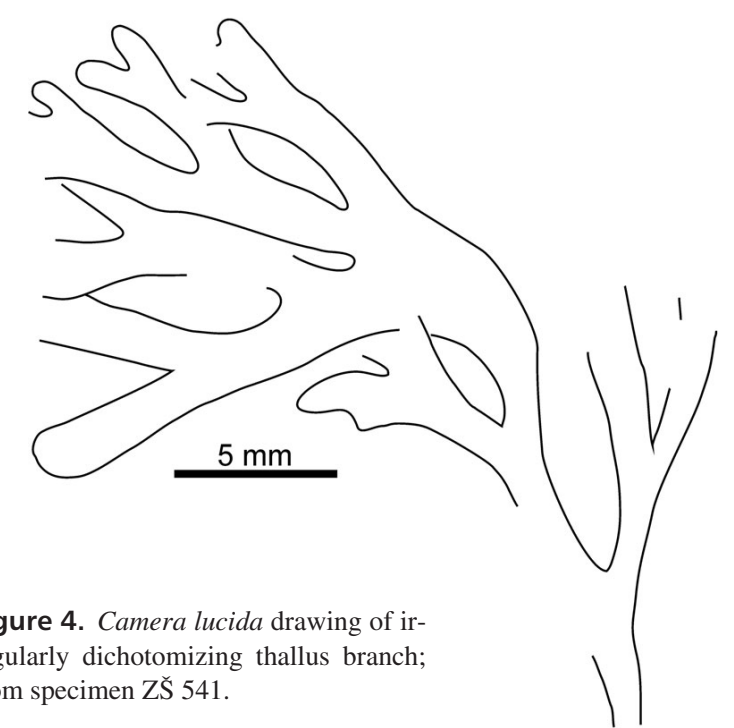

(humid phase), and Líně (arid phase) formations (Pešek 1994, 2004; Opluštil \& Cleal 2007). The Perissothallus specimens come from the Slaný Formation, which is Gzhelian (Stephanian B) in age (Němejc \& Šetlík 1950; Obrhel 1960; Havlena 1961; Pešek 1994, 2004). During this period, an extensive freshwater lake was present in the northeastern part of CWB (Lojka et al. 2010). The sedimentary record indicates that the region was governed by wet and dry seasonality (Lojka et al. 2010). Moreover, the sediment sequence contains alginite layers that formed during the phase when the lake was deepest and had its largest geographical extent; Lojka et al. (2010) report on the presence of unicellular and colonial algae such as Botryococcus Kützing and Tasmanites Newton, as well as certain thin-walled benthic algae in these layers. However, the alginite was deposited earlier (i.e. Mšenec Member) than the source sediments of the Perissothallus specimens.

The Perissothallus fossils come from the marginal development of the Lower Kounov Coal, with short episodes of water table fluctuations reflected in the alternation of mudstone and dirty coal layers. All specimens are preserved in the mudstone occurring between the arkoses at the bottom of the profile and the dirty coal (Fig. 2), and were recovered from the layer situated immediately below the lowermost dirty coal layer. Coal is visible on virtually all slabs, suggesting that the fossils comprising the assemblage all reflect the same general taphonomic history. The fossil assemblage is composed of highly fragmented remains of vascular plants, including pinnules, roots, large cordaitalean leaves, and unidentified axes. Many pinnules show evidence of early stages in the disintegration along the veins and partial skeletonization (i.e. only the venation is preserved) probably due to catabolic processes or microbial decay prior to embedding. Among the highly fragmented plant fragments are Annularia spicata (Gutbier) Schimper, A. spinulosa Sternberg, Diplazites unitus
(Brongniart) Wagner, Acitheca polymorpha Schimper, Nemejcopteris feminaeformis (Schlotheim) Barthel, Neurodontopteris neuropteroides (Göppert) Cleal, Pseudomariopteris cf. cordato-ovata (Weiss) Gillespie, Linopteris neuropteroides (Gutbier) Potonie, Callipteridium trigonum Franke, Taeniopteris sp., Dolerotheca sp. and Artisia sp., Annularia sphenophylloides (Zenker) Gutbier, Sphenophyllum oblongifolium (Germar \& Kaulfuss) Unger, and S. longifolium (Germar) Gutbier. Based on the level of degradation, these fossils probably represent a portion of the vegetation that grew some distance from the site of sedimentation. On the other hand, large cordaitalean leaves (Poacordaites sp., Cordaites sp.) and two different Samaropsis-type seeds are quite common. These forms are characterized by thick, leathery leaves, which likely were more resistant to mechanical degradation than the leaves of sphenophytes, ferns, and pteridosperms, and thus transported farther without significant destruction. As a result, it is impossible to determine whether the cordaitalean leaves stem from plants growing in close proximity to or further away from the place of sedimentation. In addition, several representatives of the pollen genus Florinites [i.e. F. antiquus Schopf, F. circularis Bharadwaj, F. junior Potonié \& Kremp, F. mediapudens (Loose) Potonié \& Kremp, F. minutus Bharadwaj, F. ovalis Bharadwaj, and F. pumicosus (Ibrahim) Schopf et al.] have been recorded for the Lower Kounov Coal (Kalibová 1960). Florinites is attributed to the Cordaitales based on in situ occurrences in Cordaitanthus Feistmantel (Brush \& Barghoorn 1962) and Florinanthus Ignatiev \& Meyen (Šimůnek et al. 2009). Unfortunately, the pollen record does not aid in determining the exact site of growth of the cordaitalean plants because Florinites can be transported over long distances by wind. Nevertheless, the overall high frequency of cordaitalean macroremains, along with the abundance of Florinites in the palynomorph assemblage, suggest that cordaitaleans constituted a significant component of the vegetation. Kalibová (1960) also found abundant spores attributable to the marattialean ferns. In addition, one lycopsid, Polysporia sp., which is regarded as a peat-forming element (Bek et al. 2008), has been reported from the mudstone layer immediately below the thin coal bed. The Lower Kounov Coal contains dispersed miospores of the Endosporites-type [E. formosus Kosanke and E. globiformis (Ibrahim) Schopf et al.] (Pešek 2004) and megaspores of Valvisisporites auritus (Zerndt) Gastaldo (Kalibová, 1959) that are all believed to have been produced by Polysporia Newberry (Bek et al. 2008). Since only a single macrofossil of Polysporia sp. has been discovered, we are unable to determine how abundant this plant was and what role it may have played in the physiognomy of the vegetation.

The abundance of large root fragments is significant with regard to assessing the palaeoenvironment at Děkov. Root fragments are variable in size (Fig. 3A); they occur in 
Figure 5. Suggested reconstruction of Perissothallus dekovensis growing on a submerged cordaitalean axis.

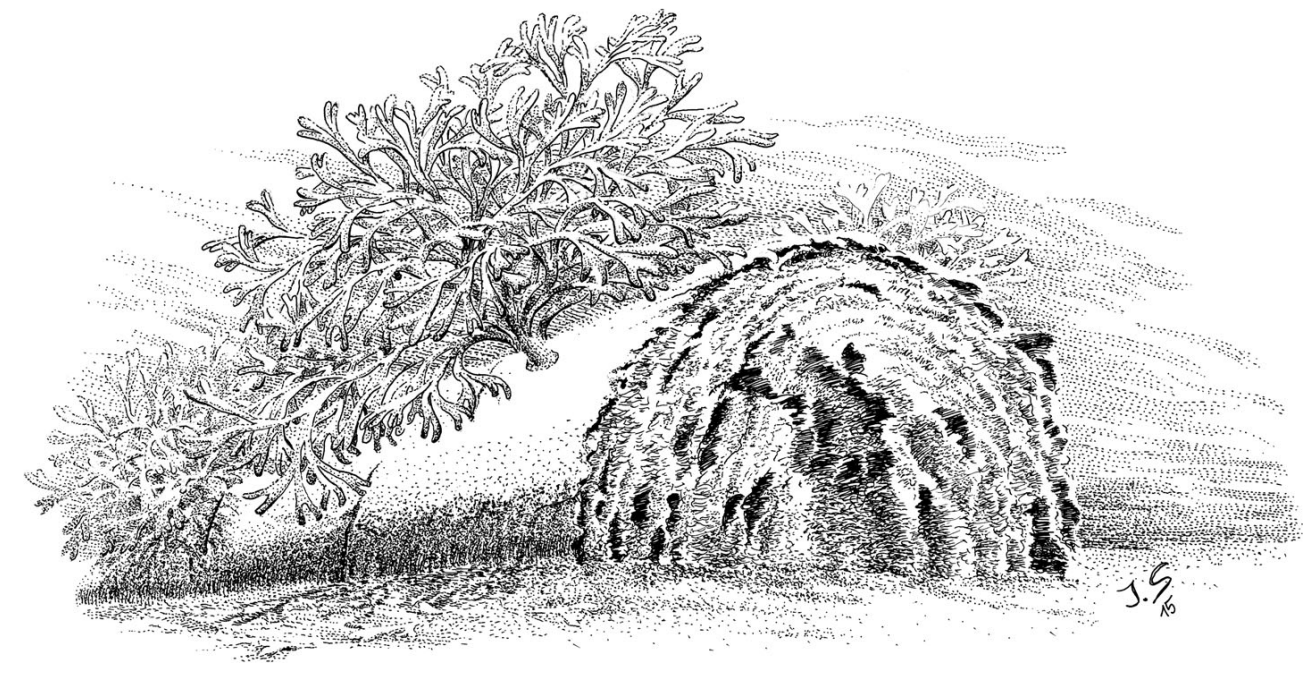

horizontal position in the sediment layers below the lower coal bed. Evidence of rhizoturbation is lacking. It appears that the assemblage consists of two morphologically different types of roots, one of which is a Pinnularia-like form attributable to sphenophytes (Jongmans 1911), which represent common elements of the flora at this locality (see above). The frequent presence of roots assignable to these plants adds support to the suggestion that sphenophytes grew close to the place of sedimentation. A second type of root may have been produced by some type of gymnosperm based on structural similarities to material described by Krings (2003).

It is especially interesting to note that one of the Perissothallus dekovensis specimens occurs attached to a relatively large plant part, probably a cordaitalean branch (Fig. 3B). This is consistent with the observations of Barthel et al. (1998) and Krings et al. (2007), who described the occurrence of $P$. densus from the Lower Permian of southwestern Germany on roots of the enigmatic gymnosperm Dicranophyllum hallei Remy \& Remy. These authors hypothesized that plants growing near or perhaps in the water may have produced roots directly into the water, or soil roots were washed free by the water, and that these roots were subsequently colonized by Perissothallus. The colonization of roots and other submerged plant parts by Perissothallus seems a plausible hypothesis (Fig. 5) because the bottoms of lakes and streams were largely composed of loose sediment and organic debris, and thus offered no secure growth sites for macroalgae that attach to the substrate by a holdfast (Krings et al. 2007).

In conclusion, the nearshore shallow-water areas of a lake or an abandoned channel that in turn was surrounded by a forest dominated by tree ferns, cordaitaleans, and lycopsids based on frequency of plant remains in combination with palynological evidence, probably represents the environment in which Perissothallus dekovensis lived. Sphenophytes including several Sphenophyllum species also grew in these areas or around the trunks of various trees. Although the Pennsylvanian coal swamp forests of Europe and North America represent the most intensively studied late Palaeozoic ecosystems, (re-)analysis of hitherto neglected or overlooked specimens and collections from historically important but no longer available localities continues to broaden our understanding of the vegetation that grew in these ancient landscapes.

\section{Acknowledgments}

Financial support was received from the Grant Agency of the Czech Republic (GAČR P210-12-2053 to J.P.). The paper is a contribution to IGCP Project 575. We are indebted to S. Opluštil for assistance with the interpretation of the geological setting, J. Svoboda for preparing Fig. 5, J. Bek for information on the palynology of the Kounov Coals, and Z. Šimůnek for granting access to the specimens kept in the Czech Geological Survey and for providing facilities during J.P.'s visit to the collection. We thank M. Mazuch for assistance with SEM at the Institute of Geology and Palaeontology, Faculty of Science, Charles University in Prague, and T. N. Taylor for proofreading the manuscript. The paper benefited from the constructive comments and suggestions of H. Kerp and J. Kvaček.

\section{References}

Andersen, R.A. 1992. Diversity of eukaryotic algae. Biodiversity and Conservation 1, 267-292. DOI 10.1007/BF00693765

Barthel, M. 1982. Die Pflanzenwelt, 36-131. In Haubold, H. (ed.) Die Lebewelt des Rotliegenden. A. Zimsen, Lutherstadt Wittenberg.

Barthel, M., Bettag, E. \& Noll, R. 1998. Dicranophyllum hallei Remy \& Remy im oberen Rotliegenden. Veröffentlichungen des Museums für Naturkunde Chemnitz 21, 5-20.

Bek, J., Drábková, J., Dašková, J. \& Libertín, M. 2008. The sub-arborescent lycopsid genus Polysporia Newberry and its spores from the Pennsylvanian (Bolsovian-Stephanian B) continental basins of the Czech Republic. Review of Palaeobotany and Palynology 152, 176-199.

DOI 10.1016/j.revpalbo.2008.05.002 
BRONGNIART, A.T. 1828-1837. Histoire des végétaux fossiles ou recherches botaniques et géologiques sur les végétaux renfermées dans les divers couches du globe. Dufour et d'Ocagne, Paris \& Amsterdam.

BRUSH, G.S. \& BARGHOORN, E.S. 1962. Identification and structure of cordaitean pollen. Journal of Paleontology 36(6), 1357-1360.

ButTERFIELD, N.J. 2000. Bangiomorpha pubescens n. gen. n. sp.: implications for the evolution of sex, multicellularity, and the Mesoproterozoic/Neoproterozoic radiation of eukaryotes. Paleobiology 26(3), 386-404.

DOI 10.1666/0094-8373(2000)026<0386:BPNGNS >2.0.CO;2

Chapman, R.L. \& Waters, D.A. 1992. Epi- and endobiotic chlorophytes, 619-639. In ReISSER, W. (ed.) Algae and Symbioses: Plants, Animals, Fungi, Viruses, Interactions explored. Biopress Ltd., Bristol, UK.

FlÜGEL, E. 1977. Fossil Algae. xiii +375 pp. Springer Verlag, Berlin/Heidelberg.

FRITSCH, F.E. 1961. The Structure and Reproduction of the Algae. Volume I. 791 pp. Cambridge University Press, Cambridge.

Garcia, A. \& Playford, G. 2007. The fossil record of the algae, 104-128. In McCARThy, P.M. \& ORChard, A.E. (eds) Algae of Australia. CSIRO Publishing, Melbourne.

Goff, L.J. 1983. Algal Symbiosis. A Continuum of Interaction Strategies. 226 pp. Cambridge University Press, Cambridge.

Graham, L.E., Graham, J.M. \& Wilcox, L.W. 2009. Algae. $2^{\text {nd }}$ Edition. 616 pp. Benjamin Cummings (Pearson), San Francisco.

Havlena, V. 1961. Svrchnopaleozoické kontinentální uloženiny a jejich fytostratigrafie v měřitku geologických stupňủ a podstupňu. Časopis pro mineralogii a geologii 6, 82-91. [in Czech with English summary]

Jongmans, W.J. 1911. Anleitung zur Bestimmung der Karbonpflanzen West-Europas mit besonderer Berücksichtigung der in den Niederlanden und den benachbarten Ländern gefundenen oder noch zu erwartenden Arten. I Band. Thallophytae, Equisetales, Sphenophyllales. Mededeelingen van de Rijksopsporing van Delfstoffen 3, 1-482.

Kalibová, M. 1959. Rod Valvisisporites (Ibrahim 1933) Pot. et Kr. 1954 (Triletes auritus Zerndt, typ II Zerndt) a jeho druhy $\mathrm{v}$ českém permokarbonu. Věstník Ústředního ústavu geologického 34, 429-436. [in Czech with English summary]

KaLiBovÁ, M. 1960. Sporenerforschung im Kounov-Flöz des Schachts František in Lhota pod Džbánem im Kladno-Rakovník-Becken. Sborník Ústredního ústavu geologického 27, 81-97.

Keith, S.A., Kerswell, A.P. \& Connolly, S.R. 2014. Global diversity of marine macroalgae: environmental conditions explain less variation in the tropics. Global Ecology and Biogeography 23, 517-529. DOI 10.1111/geb.12132

KeRP, H. \& FichteR, J. 1985. Die Makrofloren des saarpfälzischen Rotliegenden (?Ober-Karbon - Unter-Perm; SW-Deutschland). Mainzer geowissenschaftliche Mitteilungen 14, 159-286.

KRINGS, M. 2003. A pteridosperm stem with clusters of shootborne roots from the Namurian B (Upper Carboniferous) of Hagen-Vorhalle (Germany). Review of Palaeobotany and Palynology 123, 289-301. DOI 10.1016/S0034-6667(02)00218-X

KRINGS, M. \& ButZMAnN, R. 2005. Haeringiella multifidiformis gen. et sp. nov., an uncalcified alga from the lower Oligocene (Tertiary) of Bad Häring, Austria. Botanische Jahrbücher für Systematik, Pflanzengeschichte und Pflanzengeographie 126, 177-186. DOI 10.1127/0006-8152/2005/0126-0177

Krings, M., Klavins, S.D., Barthel, M., Lausberg, S., Serbet,
R., TAYloR, T.N. \& TAYlor, E.L. 2007. Perissothallus, a new genus for Late Pennsylvanian-Early Permian noncalcareous algae conventionally assigned to Schizopteris (aphleboid foliage). Botanical Journal of the Linnean Society 153, 477-488. DOI 10.1111/j.1095-8339.2007.00616.x

KRINGS, M. \& MAYR, H. 2004. Bassonia hakelensis (Basson) nov. comb., a rare non-calcareous marine alga from the Cenomanian (Upper Cretaceous) of Lebanon. Zitteliana A 44, 105-111.

KRS, M. \& PRUNER, P. 1995. Palaeomagnetism and palaeogeography of the Variscan formations of the Bohemian Massif, comparison with other European regions. Journal of the Czech Geological Society 40(1-2), 3-46.

Lojka, R., SÝkorová, I., Laurin, J., Matysová, P. \& Matys GrYGAR, T. 2010. Lacustrine couplet-lamination: evidence for Late Pennsylvanian seasonality in central equatorial Pangaea (Stephanian B, Mšec Member, Central and Western Bohemian basins). Bulletin of Geosciences 85, 709-734.

DOI 10.3140/bull.geosci. 1210

NĚMEJC, F. 1938. The Sphenopterides of the coalbasins in Central Bohemia (II part). Palaeontographica Bohemiae 16, 1-32.

NĚMeJC, F. \& ŠEtLík, J. 1950. Pokračování v paleobotanických a stratigrafických výzkumech v oblasti plzeňské. Věstník Ústředního ústavu geologického, Zprávy o výzkumu v roce 1949, 167-168. [in Czech with English summary]

Norton, T.A., Melkonian, M. \& Andersen, R.A. 1996. Algal biodiversity. Phycologia 35, 308-326. DOI 10.2216/i0031-8884-35-4-308.1

OBRhel, J. 1960. Zwei Funde aus oberen Stefanien des Kladnoer Steinkohlenbeckens [?Dolerotheca fertilis (Renault) und Callipteridium trigonum Franke]. Sborník Ústředního ústavu geologického 25, 85-97.

Opluštil, S. \& Cleal, C.J. 2007. A comparative analysis of some Late Carboniferous basins of Variscan Europe. Geological Magazine 144, 417-448. DOI 10.1017/S0016756807003330

OpluštiL, S. \& PEŠEK, J. 1998. Stratigraphy, palaeoclimatology and palaeogeography of the Late Palaeozoic continental deposits in the Czech Republic, 597-620. In Crasquin-Soleau, S., Izart, A., Vaslet, D. \& De Wever, P. (eds) Peri-Tethys: Stratigraphic Correlations 2. Geodiversitas 20.

PEŠEK, J. 1994. Carboniferous of Central and Western Bohemia (Czech Republic). 60 pp. Czech Geological Survey, Prague.

PEŠEK, J. 2004. Late Paleozoic limnic basins and coal deposits of the Czech Republic. Folia Musei rerum naturalium Bohemiae occidentalis, Geologica 1, 1-188.

RIDING, R. 1991. Calcareous Algae and Stromatolites. $\mathrm{x}+571$ pp. Springer Verlag, Berlin/Heidelberg.

Round, F.E. 1981. The Ecology of Algae. 653 pp. Cambridge University Press, Cambridge MA.

ŠIMƯNEK, Z., OPLUŠTIL, S. \& DRÁBKovÁ, J. 2009. Cordaites borassifolius (Sternberg) Unger (Cordaitales) from the Radnice Basin (Bolsovian, Czech Republic). Bulletin of Geosciences 84, 301-336. DOI 10.3140/bull.geosci.1130

Sternberg, K.M. Graf von (Presl, C.B. \& Corda, A.J. co-authors) 1838. Versuch einer geognostisch-botanischen Darstellung der Flora der Vorwelt, vol. II, 7/8, 81-220. Gotlieb Hässe \& Söhne, Prague.

TAPPAn, H. 1980. The Paleobiology of Plant Protists. xxi +1028 pp. W.H. Freeman and Company, San Francisco CA.

TAYLOR, T.N., TAYlor, E.L. \& KRINGS, M. 2009. Paleobotany. The Biology and Evolution of Fossil Plants. $2^{\text {nd }}$ Edition. xxi + 1230 pp. Elsevier/Academic Press Inc., Burlington MA, London, San Diego CA, New York NY. 